Ann. Biol. anim. Bioch. Biophys., 1978, 18 (2 B), 535-540.

\title{
Hormonal control of postnatal maturation of the seminiferous cord
}

by R. S. BRESSLER

\author{
Department of Anatomy, \\ Mount Sinai School of Medicine of the \\ City University of New York, \\ One Gustave Levy Place, \\ New York, New York 10029, U. S. A.
}

Summary. Experiments involving the transplantation of testes from newborn mice into normal, hypophysectomized and testosterone-treated hypophysectomized adult hosts demonstrated that the pituitary gland was essential for normal development of the peritubular myoid cells and Sertoli cells. The ability of testosterone to partially replace the effects of the pituitary gland indicated that LH is involved. In order to determine if the retarded development seen in testosterone-treated hypophysectomized hosts results from an inadequate delivery to the seminiferous cords, pellets of crystalline testosterone were implanted into the testes of 7 day old rats. At 17, 23 and 28 days of age precocious canalization of the seminiferous cords was observed demonstrating a direct effect of testosterone on tubule development. Preliminary results of ultrastructural studies indicate that Sertoli cell junctions are more abundant in the treated testes than in contralateral or sham operated control testes. Daily injections of Depo-Provera, alone or with FSH and LH severely retards canalization of the seminiferous cords.

\section{Introduction.}

At birth the testis in the rat and mouse contains solid cords of cells which consist of gonocytes and relatively undifferentiated Sertoli cells. These cords lie in a stroma of fibroblasts. During the second and third postnatal weeks a number of developmental events take place. Among these are; development of the peritubular myoid cells (Leeson and Leeson, 1963 ; Ross, 1967), onset of the first wave of meiosis (Clermont and Perey, 1957), maturation of the Sertoli cells including formation of their specialized junctions (Flickinger, 1967 ; Gilula ef al., 1976) which are the basis of the blood testis barrier (Dym and Fawcett, 1970 ; Ross, 1970), canalization of the seminiferous cords and increased secretion by Sertoli cells (Vitale et al., 1973). Thus by the end of the third week the adult morphology has been established and all of its constituent cell types are well differentiated, except for the germ cells, which nevertheless are well into the first wave of spermatogenesis. However, the hormonal control of seminiferous cord maturation is not well established. 


\section{Development of the tunica propria}

A report by de la Balze et al. (1960) described the transformation of fibroblasts in the tunica propria into attenuated cells as one of the first indicators of puberal maturation in the human testis. Those authors noted that development was most pronounced in portions of the tubular wall which were adjacent to Leydig cells. They concluded that development and/or maintenance of the peritubular tissue are regulated by androgens. Studies of the tunica propria of adult human seminiferous tubules revealed corresponding attenuated cells which exhibit certain ultrastructural features of smooth muscle (Ross and Long, 1966). Although little is known concerning the development of these contractile cells in the human, a transition of peritubular fibroblasts into myoid cells at the onset of puberty has been described in various mammals (Leeson and Leeson, 1963 ; Ross, 1967 ; Kormano and Hovatta, 1972) and birds (Rothwell and Tingari, 1974).

The establishment of the peritubular myoid cell component at a time coincident with other maturational changes suggested that its development is as much dependent on hormonal factors as is development of other testicular cell types. In experiments aimed at determining an endocrine basis for the development of the peritubular myoid cells, Bressler and Ross (1972) implanted testes of newborn mice directly into the testes of normal, hypophysectomized and testosterone-treated, hypophysectomized hosts. In normal hosts the myoid cells differentiated at a rate comparable to differentiation in the testes of sibling controls. However, the tunica propria of implants in hypophysectomized hosts retained the characteristics found in testes of newborn animals. An intermediate response was seen in implants in testosterone-treated hypophysectomized hosts. It was concluded that an intact pituitary is necessary for the development of peritubular myoid cells, but the role of various pituitary hormones could not be fully assessed. The partial replacement value of testosterone indicated that LH is involved by way of Leydig cell stimulation. From this point of view, it is interesting that Hovatta (1972) noted an enhancement of the development of the peritubular myoid cells in seminiferous tubule cultures treated with HCG or testosterone and degenerative changes when grown in the presence of cyproterone acetate. Thus there is abundant evidence that differentiation of the boundary tissue is androgen dependent. The failure of testosterone to provide complete replacement for the pituitary gland may reflect the failure of adequate amounts to reach the seminiferous cords.

Bressler and Ross (1972) noted that although all the cells surrounding the seminiferous cords of the newborn appeared to be homogeneous in appearance, only the innermost ones acquired contractile features. Since the more peripheral cells of the boundary tissue can develop a myoid appearance under experimental conditions (Bressler and Ross, 1973), a selective differentiation of the innermost cell layer cannot be accounted for by a direct action of pituitary hormones. The correlation between growth of the seminiferous cord and the degree of differentiation of the myoid cells suggested that pituitary hormones act on an intermediate cell type in the seminiferous epithelium which in turn influences differentiation of contractile elements in the adjacent peritubular cells. On the basis of the parallel postnatal differentiation of Sertoli cells and myoid cells they suggested that the Sertoli cells regulate myoid cell differentiation. 


\section{Endocrine control of Sertoli cell maturation}

In view of the correlations of Sertoli cell maturation with the differentiation of the tunica propria, the electron microscope preparations previously used to study the differentiation of peritubular myoid cells were reexamined to evaluate pituitary effects on Sertoli cell maturation (Bressler, 1976). Development of Sertoli cells (judged by the number of cells containing nucleolonema) in a variety of hormonal environments paralleled that seen for peritubular myoid cells. Sertoli cells of the newborn mouse testis fail to mature in the absence of the pituitary gland. Testosterone was able to partially replace the function of the missing pituitary gland. Perhaps a more meaningful criterion of Sertoli cell development is the establishment of Sertoli cell junctions indicative of the formation of the blood-testis barrier. These were conspicuous in implants recovered from normal adult hosts but were not found in implants recovered from hypophysectomized hosts.

It is difficult to reconcile these findings with those of Vitale ef al. (1973) who reported that development of the blood-testis barrier was delayed but not arrested in rats whose gonadotropin output was surpressed by estrogen or clomiphene treatment. They concluded that the formation of occluding junctions between Sertoli cells does not appear to be directly dependent upon gonadotropins. In contrast, de Kretser and Burger (1972) reported finding only immature Sertoli cells in hypogonadotropic men ranging between 17 and 37 years of age. In some cases this represents a delay of as long as three times the usual maturation age - proportionately much longer than the seven day delay reported by Vitale ef al. for rats. This is not a question of the Sertoli cells losing their ability to differentiate since after treatment with pituitary and chorionic gonadotropins, Sertoli cells of hypogonadotropic patients exhibited all of the characteristics of mature Sertoli cells. The findings of de Kretser and Burger are supported by those of Bressler (1976) which demonstrate that in the mouse the postnatal maturation of Sertoli cells is dependent upon the pituitary gland. As is the case with peritubular myoid cells, testosterone is involved. From this viewpoint it is interesting that both Sertoli and peritubular myoid cells fail to mature in Tfm mice (Chung, 1974).

\section{Effects of high local levels of testosterone on seminiferous cord development}

Although testosterone effects the maturation of germ cells (Clermont and Harvey, 1966), peritubular myoid cells (Bressler and Ross, 1972), and Sertoli cells (Bressler, 1976) in hypophysectomized rats and mice it does not evoke the same degree of development which occurs in intact animals. The failure of testosterone to do so may indicate that the amount reaching the seminiferous cords is insufficient to stimulate development. It has been shown that lower doses of testosterone are needed to maintain spermatogenesis in hypophysectomized rats when the hormone is placed in the testis than when it is systemically administered (Droskin, 1944). Indeed precocious spermatogenesis has been observed in cases of Leydig cell tumors in boys (Gittes ef al., 1970 : Steinberger ef al., 1973). The prepubertal appearance of the contralateral 
testis indicates that precocious maturation in the affected testis results from local effects. In a recent study (Bressler, 1977 ; Bressler and Lustbader, 1978) pellets of crystalline testosterone were implanted into the right testis of seven day old rats in order to provide a high local level of that hormone. At 10, 17, 23 and 28 days of age development of the seminiferous tubules in the treated testis was compared to that in the contralateral testis and in testes of sham operated controls. Development of the seminiferous tubules, as judged by lumen formation, was more extensive in the treated testes at 17, 23 and 28 days.

Testosterone has been shown to influence Sertoli cell secretion (Hansson et al., 1975) and junction formation (Bressler, 1976), processes which occuring together should result in the containment of fubule secretions and formation of a lumen. It is likely that the more extensive lumen formation in the treated testis results from those effects of testosterone. Indeed, preliminary electron microscope observations indicate that Sertoli cell junctions are more abundant in the treated testis than in contralateral or sham operated controls. Seminiferous cord and tubule diameters were also measured since that parameter has been used historically to assess testicular development. However, tubule diameter did not correlate with lumen formation. It was concluded that lumen formation was a befter parameter of development than tubule diameter, particularly in experimental conditions where non-developmental events may influence the size of the tubules.

These studies demonstrate that testosterone, when present in sufficiently high intratesticular levels, accelerates the postnatal development of the seminiferous tubules in the rat. However, a direct role for the pituitary gland cannot be ruled out. Unlike earlier investigations in hypophysectomized animals, it is present both in these studies and in cases of Leydig cell tumors. Although gonadotropin levels were not measured the contralateral testes appeared to be less developped than sham operated controls, an observation which may indicate inhibition of pituitary function. Since the differences between these two groups were not statistically significant, additional studies are required to resolve this question. It is interesting that seminiferous cords of rats treated with LH antiserum fail to develop lumens. Similar treatment with FSH antiserum does not inhibit canalization of the cords (Madhwa Raj and Dym, 1976). Those findings compliment the observations of Bressler and Lustbader (1978) in that lumen formation fails to occur in circumstances of reduced testosterone levels but is unaffected by the absence of FSH. From the above it appears that testosterone is the major factor in the postnatal development of the seminiferous tubules in the mouse and rat.

\section{Effects of progestin on seminiferous tubule development}

Recent attempts to develop a male contraceptive agent have included the use of medroxyprogesterone acetate, a progestin which is not readily metabolized to androgenic compounds (Frick and Bartsch, 1976 ; MacLeod, 1965) and which inhibits testosterone production (Gordon et al., 1970 ; Satyaswaroop and Gurpide, personal communication). In order to assess the effects of this steroid on seminiferous tubule development rats were given daily subcutaneous injections of Depo Provera $(500 \mathrm{ugm} /$ $100 \mathrm{gm}$ body weight) from 7 to 28 days of age. Although too few animals have as 
yet been studied for statistical analysis, a striking difference can be seen with respect to canalization of the lumens between treated and control groups. Lumen formation is scarce in the seminiferous cords of the treated animals.

Provera may be acting by inhibiting the pituitary gland or by directly affecting testicular function (Satyaswaroop and Gurpide, personal communication). In order to distinguish between these possibilities another series of rats received daily subcutaneous injections of both provera and gonadotropins (bovine $\mathrm{LH}, 50 \mathrm{ugms} / 100 \mathrm{gm}$ body weight and ovine FSH, $12.5 \mathrm{ugm} / 100 \mathrm{gm}$ body weight). Preliminary results indicate that, as with Provera alone, development of lumens in these animals is retarded. In view of the rapid turnover of gonadotropins, analyses of gonadotropin levels must be performed before conclusions can be drawn.

$27^{e}$ Congrès international des Sciences physiologiques,

Symposium « Germ and somatic cell interaction 》

Paris, 21-23 juillet 1977.

Acknowledgements. - Some of the work included in this review has been done in collaboration with Drs. Michael Ross and P. G. Satyaswaroop and Messrs. Jonathan M. Barasch and lan J. Lustbader. The secretarial services of Mrs. Barbara Park are gratefully acknowledged.

Résumé. Des expériences de greffe du testicule de souriceau nouveau-né, dans des adultes normaux, hypophysectomisés ou hypophysectomisés et recevant de la testostérone, ont montré que l'hypophyse est essentielle pour le développement normal des cellules péritubulaires myoïdes et des cellules de Sertoli. La capacité de la testostérone à remplacer partiellement l'effet de l'hypophyse montre que LH est impliquée. Afin de déterminer si le retard de développement observé dans le receveur hypophysectomisé, traité par la testostérone, résulte d'un passage insuffisant vers les tubes séminifères, on a implanté des pellets de testostérone cristallisée dans le testicule du rat âgé de 7 jours. A l'âge de 17,23 et 28 jours, on a remarqué la canalisation précoce des tubes séminifères, indiquant un effet direct de testostérone sur le développement tubulaire. Le résultat préliminaire d'études ultrastructurales indique que les jonctions des cellules de Sertoli sont plus nombreuses dans le testicule traité que dans le testicule contralaféral ou dans le testicule témoin ayant subi une opération fantôme. L'injection quotidienne de Depo-Provera, seule ou avec FSH et LH, retarde sévèrement la canalisation des tubes séminifères.

\section{References}

BRESSLER R. S., 1976. Dependence of sertoli cell maturation on the pituitary gland of the mouse. Am. J. Anat., 147, 447-455.

BRESSLER R. S., 1977. Testosterone accelerates seminiferous tubule development in the rat. Anat. Rec., 187, 76 (Abstr.).

BRESSLER R. S., LUSTBADER I. J., 1978. Effect of testosterone on development of the lumen in seminiferous tubules of the rat. Andrologia (in press).

BRESSLER R. S., ROSS M. H., 1972. Differentiation of perifubular myoid cells of the testis : effects of intratesticular implantation of newborn mouse testes into normal and hypophysectomized adults. Biol. Reprod., 6, 148-159.

BRESSLER R. S., ROSS M. H., 1973 . On the character of the monolayer outgrowth and the fate of the peritubular myoid cells in cultured mouse testis. Exp. Cell Res., 78, 295-302.

CLERMONT Y., HARVEY S. C., 1966. Effects of hormones on spermatogenesis in the rat, 173-196. In WOLSTENHOLME G. E. W., O'DONNER M., Endocrinology of the testis. Little, Brown \& Co. (Ciba Foundation Colloquia on Endocrinology, vol. 16), Boston. 
CLERMONT Y., PEREY B., 1957. Quantitative study of the cell population of the seminiferous tubules in immature rats. Am. J. Anat., 100, 241-268.

CHUNG K. W., 1974. Fine structure of sertoli cells and myoid cells in mice with testicular feminization. Fert. Ster., 25, 325-335.

DE KRETSER D. M., BURGER H. G., 1972. Ultrastructural studies of the human sertoli cell in normal men and males with hypogonadotropic hypogonadism before and after gonadotropic treatment, 640-655. In SAXENA B. B., BELING C. G., GANDY H. M., Gonadotropins, J. Wiley and Sons, New York.

DE LA BALZ F. A., MACINI R. A., ARRILLAGA F., ANDRADA J. A., VILAR O., GURTMAN A. I., DAVIDSON O. W., 1960. Pubertal maturation of the normal human testis. A histological study. J. clin. Endocrinol., Metab., 20, 266-285.

DVOSKIN S., 1944. Local maintenance of spermatogenesis by intratesticularly implanted pellets of testosterone in hypophysectomized rats. Am. J. Anat., 75, 289-317.

DYM M., FAWCETT D. W., 1970. The blood testis barrier in the rat and the physiological compartmentation of the seminiferous epithelium. Biol. Reprod., 3, 308-326.

FLICKINGER C. J., 1967. The postnatal development of the sertoli cells of the mouse. $Z$. Zellforsch., 78, 92-113.

FRICK J., BARTSCH G., 1976. Steroidal compounds (injectable and implants) affecting spermatogenesis in man. J. Reprod. Fert. Suppl., 24, 35-47.

GILULA N. B., FAWCETT D. W., AOKI A., 1976. The sertoli cell occluding junctions and gap junctions in mature and developing mammalian testis. Dev. Biol., 50, 142-168.

GITTES R. F., SMITH G., CONN C. A., SMITH F., 1970. Local androgenic effect of interstitial cell tumor of the testis. J. Urology, 104, 774-777.

GORDON G. G., SOUTHERN A. L., TOCHIMOTO S., OLIVO J., ALTMAN K., RAND J., LEMBERGER L., 1970. Effect of medroxyprogesterone acetate (Provera) on the metabolism and biological activity of testosterone. J. clin. Endocrinol. Metab., 30, 449-456.

HANSSON V., WEDDINGTON S. C., NAESS O., ATTRAMADAI A., FRENCH F. S., KOTITE N., NEYFEH S. N., RITZEN G. M., HAGENAS L., 1975. Testicular androgen binding protein (ABP). A parameter of sertoli cell secretory function, 323-336. In FRENCH F. S., HANSSON V., RITZEN G. M., NEYFEH S. N., Hormonal regulation of spermatogenesis. Plenum Press, New York.

HOVATTA O., 1972. Effect of androgens and antiandrogens on the development of myoid cells of the rat seminiferous tubules (organ culture). Z. Zellforsch, 131, 299-308.

KORMANO M., HOVATTA O., 1972. Contractility and histochemistry of the myoid cell layer of the rat seminiferous tubules during postnatal development. Z. Anat. Entwickl. Gesch., 137, 239248.

LEESON C. R., LEESON T. S., 1963. The postnatal development and differentiation of the boundary tissue of the seminiferous fubule of the rat. Anat. Rec., 147, 243-259.

MADWA RAJ H. G., DYM M., 1976. The effects of selective withdrawal of FSH or LH on spermatogenesis in the immature rat. Biol. Reprod., 14, 489-494.

MacLEOD J., 1965. Human seminal cytology following the administration of certain antispermatogenic compounds, 93-123. In AUSTIN C. R., PERRY J. S., Agents affecting fertility. Churchill, London.

ROSS M. H., 1967. The fine structure and development of the peritubular contractile cell component in the seminiferous tubules of the mouse. Am. J. Anat., 121, 523-558.

ROSS M. H., 1970. The sertoli cell and the blood-testicular barrier : An electron-microscopic study. Fortschr. Androl., Morph. Aspects Androl., 1, 83-86.

ROSS M. H., LONG I. R., 1966. Contractile cells in human seminiferous tubules. Science, 153, 1271-1273.

ROTHWELL B., TINGARI M. D., 1974. The ultrastructural differentiation of the boundary tissue of the seminiferous tubule in the testis of the domestic fowl. Br. vet. J., 130, 587-592.

STEINBERGER E., ROOT A., FICHER M., SMITH K. D., 1973. The role of androgens in the initiation of spermatogenesis in man. J. clin. Endocrinol. Metab., 37, 746-751.

VITALE R., FAWCETT D. W., DYM M., 1973. The normal development of the blood-testis barrier and the effects of clomiphene and estrogen treatment. Anat. Rec., 176, 333-344. 